\title{
Sir Malcolm Robertson and the British trade mission to South America in 1929.
}

\author{
Gaynor Johnson
}

\begin{abstract}
This article evaluates the British government's attitude to the trade mission to Argentina led by Viscount D'Abernon in 1929 and analyses its impact on Anglo-Argentina commercial relations. It explores notions of informal empire in South America and the dynamics of Anglo-Argentine and US-Argentine relations. At the centre of the analysis is Sir Malcolm Robertson, the British ambassador to Buenos Aires, whose activities were negatively impacted by British prejudice towards the region. This is the first evaluation of the mission since the 1980s and is based on a wider reading of UK archives. It is the first analysis of Robertson's diplomatic career.
\end{abstract}

Key words: Britain; Argentina; diplomats; diplomacy; commerce.

Britain's relations with South America during the first half of the twentieth century have not received a great deal of historical attention. What little material exists has focussed on the technical aspects of questions relating to the application of tariffs, stamp duty and the operation of most favoured nation status agreements. Within this narrow framework, the overwhelming focus has been on Britain's relations with Argentina and their bearing on United States' diplomatic strategy in South America. 
In particular, scholars have addressed the turf war between the British and American governments for the Argentine markets, especially in beef products, railway rolling stock and in fine textiles. Little attempt has been made to view these issues through the lens of British commercial diplomacy. This is, of course, a large subject, and one that cannot be addressed in its entirety here. Yet, the parameters of this topic can he understood in part through the examination of a single case study; the context and consequences of the British government's decision to despatch a trade mission to South America in the summer of 1929. Led by the former ambassador to Berlin, Viscount D'Abernon, its principal focus was on Argentina and Brazil. The work of the mission was first examined by Roger Gravil as long ago as the 1970s and has only recently been reappraised by the present author, based on different documentation, as part of a major new international study of Britain's relations with South America. ${ }^{1}$ However, this fresh examination suggests that, for reasons that will become apparent in this article, the British diplomatic and political context to the mission are arguably of greater significance to scholars of Anglo-Argentine relations than the endeavours of D'Abernon and his colleagues. Of particular importance is the role played by the ambassador to Buenos Aires, Sir Malcolm Robertson. It fell to him the task of interpreting the terms of the commercial agreement and it was he who was in the firing line when the negotiations stalled in the autumn of 1929. This article analyses reasons why Robertson was made a scapegoat for the British 
government's hesitancy in offering the Argentines a concrete commitment to implement the terms of the agreement. It also affords an opportunity to examine the way in which three departments of the British government worked together to develop a commercial policy in a region of the world whose potential had hitherto been undervalued. There was a clear departmental hierarchy in how the Foreign Office, the Treasury and the Board of Trade discussed and formulated policy. This placed the Foreign Office at the top of the chain of influence in a distinct senior role that was in marked contrast to the turf wars of the earlier 1920s with the Treasury concerning the German reparation question.

As has already been suggested, the historiography of Britain's relations with South America in the early twentieth century is very small; there has been little discussion about cultural, political or diplomatic issues. ${ }^{2}$ Within that literature, such analysis of the work of the 1929 trade mission as there has been is concerned with D'Abernon's role as its head. Furthermore, contemporary accounts by both D'Abernon and Robertson emphasise at length what they deemed to be the mission's success. ${ }^{3}$ This view remained unchallenged until Gravil's account was published in the 1970s. ${ }^{4}$ He concluded that the optimism of D'Abernon and Robertson was unfounded and that the trade mission had actually legitimised British commercial exploitation of Argentina. ${ }^{5}$ This view was then contextualised in a series of studies by American scholars, notably Paul B. Goodwin, Carl Solberg and Joseph S. Tulchin, who mapped the objectives of the mission and Anglo- 
Argentine commercial relations against the objective of the United States in South America. ${ }^{6}$ They argued that this region became a commercial battleground between Britain and the United States in the 1920s; that the origins of that rivalry went as far back as the mid nineteenth century and that it continued well into the Cold War era. The American literature makes full reference to Argentine sources as well as some of the British archival material. These studies do not concern themselves directly with the success of the mission, but assume that the rationale behind British commercial policy was flawed.

These later historical accounts relate closely to scholarship on international political economy in South America, where the 1929 mission is viewed as a case study in dependence theory. This is premised on the view that most relations between states are determined by a pattern of domination and subservience; a hypothesis expressed in the work of the Chilean political scientist, Theotonio dos Santos. ${ }^{7}$ To him, the reason why Britain was able to secure such a favourable deal with the government of the charismatic Argentine President, Hipólito Yrigoyen in 1929 was because of British predominance in technological, commercial and capital resources; in much the same way as the same resources were used to subjugate the colonies that made up the British Empire. ${ }^{8}$ This notion of informal empire resulted in a close relationship between British venture capitalists and Argentine oligarchs rather than a commercial arrangement that benefitted all areas of the countries' economies. Paul Goodwin has 
argued that hitherto international political economists have failed to understand the importance of the venture capitalist strata, and have focussed too much on the wider commercial relationship between Britain and the countries of South America. ${ }^{9}$

Goodwin views the commercial relationship between Britain and Argentina in the 1920s as fundamentally unequal; a conclusion that neither D’Abernon nor Robertson would have disputed.

The question of unequal status was also reflected in the way in which the British Foreign Office viewed South America. While the official position was that it was a region of high importance, the overwhelming diplomatic focus of the Foreign Office remained firmly fixed on Europe and North America. The 1929 trade mission did nothing to change that. Indeed, while there were to be a number of rumblings of discontent about Peronism in the 1950s and Argentine claims to sovereignty of the Falkland Islands and South Georgia, no major shift of emphasis within the Foreign Office occurred until the war of $1982 .{ }^{10}$ Until then, to the British government, the countries of South America occupied a strange twilight world that lay somewhere between their recognition as a collection of independent nation states and an informal extension of the British Empire. Just as there was an expectation that the Colonies would accord Britain special status in international commerce, the same was expected of South American trading partners, especially Argentina and Brazil. This was not an 'unspoken assumption' on behalf of the British government, but was, as this article will discuss, an open and clearly articulated part of 
how Whitehall and the trade mission viewed these countries. The ambiguous approach to South American diplomacy was also reflected in the British diplomatic presence based there. As it took anywhere between three and six weeks to reach the continent by boat from Britain, few high flying diplomats were attracted to postings in what was seen as a remote backwater. There were exceptions to this of course, and one of them is the subject of this article, but there was an informal prejudice also at work. Because of their willingness to take on such positions, Robertson and his ilk were frequently viewed as lacking sufficient élan for the more high profile postings in Europe and in North America. Similarly, the Foreign Office not infrequently viewed South America as a convenient dumping ground for those diplomats considered troublesome or whose competence was in question.

Of all the countries in South America, it was the modern, industrial economy of Argentina that was of greatest significance to Britain. Anglo-Argentine trade relations covered a wide range of commodities, from beef exports, synthetic fabrics to servicing the railway system, much of which had been built by British engineers in the late nineteenth and early twentieth century. Commercial relations had been formalised through the visits of a series of delegations from London to Buenos Aires: in 1911; a small entourage of British industrialists visited Buenos Aires in 1919 and the D'Abernon mission of 1929, which gave rise to the despatch of an Argentine delegation to London in 1933 and the conclusion of the Roco-Runciman agreement. The aim of this article is to 
broaden our understanding of Britain's relations with Argentina during the 1920s by placing the aftermath of the D'Abernon mission in its wider political and diplomatic context. International commerce cannot be fully understood any other way, certainly not between modern industrial countries. It will briefly outline the main objectives of the 1929 mission, and will then move on to discuss how the British and Argentine governments interacted in the months that followed to bring the agreement to the point of signature. The main focus will be on the contribution of the British head of mission in Buenos Aires, Sir Malcolm Robertson ${ }_{2}$ to the negotiations and how they were viewed in London and in Argentina. This offers fresh insights into how the British government actually viewed commercial relations with Argentina and the strategies it was prepared to adopt in order to obtain an agreement that was in Britain's interests. It also provides an important opportunity to observe the way in which the Foreign Office, the Board of Trade and the Treasury were capable of working together regarding an issue of mutual importance.

Tariffs and their imposition was a sensitive and controversial issue for the British government in the early decades of the twentieth century. The context to the debate was an era when a period of stagnation within the British Empire had done not enough to obviate the cost of its administration. The aftermath of the First World War had shifted the tariff debate onto trade with Europe. At this time, the imposition of tariffs was also forming an important part of Argentine economic planning. ${ }^{11}$ The 
rapidly expanding economy sought to optimise its exports of agricultural and cattle products. In this it was largely successful, with as much as forty percent of goods going for export by $1923 .{ }^{12}$ At the same time, this expansion took place at a time when many Argentine industrialists wished to broaden the economy into consumer goods. It coincided with the adverse effects of global overproduction of cattle products which resulted in a dramatic decline in earnings from those exports. ${ }^{13}$ However, it was the decision of the French, Spanish and Italian governments to raise tariffs on imports from Argentina in the mid 1920s that created the possibility for the British government to raise the question of tariffs with the Argentines. In 1927, another opportunity occurred when the United States government prohibited imports of fresh and refrigerated Argentine meat. ${ }^{14}$ The Yrigoyen government therefore decided that the beef trade with Britain deserved special protection. ${ }^{15}$ Consequently, when the D'Abernon mission arrived, the Argentine economy was contracting; a process which the consequences of the visit did nothing to ameliorate.

There were three principal reasons why the Anglo-Argentine commercial agreement of 1929 came into being. The first of these was the foundation of British and American commercial relations with Argentina during the early twentieth century. This was based on most favoured nation treatment of goods between the respective agreements. Regarding Britain, the Argentines operated a policy of unconditional most favoured nation status to all imports. That is, that concessions made to a third 
party were automatically added to those made to other third parties. Relations between Argentina and the United States operated differently. Here, most favoured nation status worked on the basis that an agreement granted as a concession to a third party was offered only to countries prepared to make a similar gesture. ${ }^{16}$ Yrigoyen was convinced that the British were more likely to maintain their approach to commercial relations with Argentina than the Americans. The second impetus came from the decision of the American President-elect, Herbert Hoover, to visit Argentina in December 1928. He was keen to play down any initiative that smacked of American commercial aggression in the region. ${ }^{17}$ However, Robertson was not convinced, informing the Foreign Office that: 'The United States under Hoover means to dominate this continent by hook or by crook. It is British interests that chiefly stand in the way. These are to be bought out or kicked out'. ${ }^{18}$

The principal fear was that the American government would try to buy out the British share of the Argentine railway infrastructure. On this issue, the British government had cause to be optimistic. As Robertson reported, Yirogyen was 'entirely satisfied with British capital generally and with the British railways in particular.' The British had 'loyally done their best' to help develop Argentina. And that he had little reason to see the railway franchises to 'be sold to anyone, whoever they may be...'. Yet Robertson was aware that the situation was not as straightforward as the President had made out. Shares could be bought on the open 
market and small shareholders might feel compelled to sell to larger ones and nothing could be done about that. Robertson formed the impression that Yirogoyen was keen to make sure this situation did not come about but was unclear how he could prevent it. Robertson also suggested that the Argentine government prohibit the sale of public utility companies into other hands except with government consent. Robertson noted that the 'alarm' at the prospect of the sale of the British railways was 'widespread' across the country. ${ }^{19}$ He assured the Foreign Office that Argentine opposition to American ownership of the railway system was 'permanent', although he expected the United States government to be persistent in trying to secure a monopoly. Robertson also encouraged British pro-activity because the Anglophile Yrigoyen was aging and that there was little reason to believe that his successor might be as amenable to concluding a commercial agreement with Britain, especially one on such favourable terms. ${ }^{20}$

Robertson's attitude and his good personal relationship with Yrigoyen created the circumstances for the third factor that influenced the British government's decision to despatch a commercial mission to South America. After Hoover's delegation had departed, advisers and confidants close to Yrigoyen informed Robertson that the President would welcome a similar visit from Britain because, as D'Abernon later put it, the British were 'regarded as less aggressive, less domineering and less inclined to use force in support of financial and commercial claims' ${ }^{21}$ At least two of 
these factors place Robertson at the heart of the thinking that led to the decision to despatch a British commercial mission to South America, which the Board of Trade took in July 1929. Yet, Robertson's role has been downplayed, even overlooked by many historians who have examined Britain's relations with that part of the world. This article aims in part to correct this.

The British 1929 trade mission consisted of six members: Viscount D’Abernon; Sir William Clare Lees, a cotton textile manufacturer; Julian Piggott of Roland and Piggott, a nominee of the National Federation of Iron and Steel Manufacturers; W. HowardWilliams of the Agricultural Engineers Association; H.W. Wiswould, of the Department of Overseas Trade and H.Owen Chalkley, one of the commercial counsellors of the British Embassy in Buenos Aires. Edgar Vincent, Viscount D’Abernon, born 1858, was a Liberal peer and former ambassador to Berlin, 1920-1926. His personal profile was high in 1929 because of the publication of the first volume of his Berlin diary. Before his diplomatic career, he had been a well-known international financier and was a former Governor of the Imperial Ottoman Bank. Although not a specialist on South American commerce, he was viewed as a man of the world who possessed a deep understanding of contemporary international relations. Never one for high intellectualism, D'Abernon's strategic approach was flexible and straightforward. His forte was diplomacy through personal friendship, with one commentator on the mission describing him as having the 'Nelson touch'. ${ }^{22}$ For example, when the Anglo-Argentine commercial agreement that 
emerged from the work of the mission was finally signed in December 1929, D’Abernon told Yrigoyen: 'Everything which has occurred since my return from the Argentine convinces me of the exceptional prescience of Your Excellency in initiating the negotiation. The utility of the Convention - even the necessity for it - in assuring the development of relations between our two countries becomes every day more apparent. ${ }^{, 23}$ At the same time, it was important to D'Abernon that the commercial agreement would be merely the starting point of a closer relationship between the two countries. It would be 'deplorably defective' to assume that by concluding an agreement based on reciprocal most favoured nation status, the future development of trade relations between the two countries would be assured. ${ }^{24}$ In fact, it was incumbent on the British government to raise its commercial game in South America; that hitherto there had been too much 'selfsatisfied inactivity., ${ }^{25}$

Sir Malcolm Robertson, born 1877, had been appointed ambassador to Argentina in 1927. He had been minister plenipotentiary in Buenos Aires since 1925, and concurrently held the post of Minister Plenipotentiary to the Republic of Paraguay until 1929. He had also enjoyed a stint in Rio de Janeiro as chargé d'affaires between 1912 and 1915. Consequently, few British diplomats possessed knowledge of South American diplomacy, commerce and politics to rival Robertson. While he did not leave a large cache of private papers, his archival footprint is extensive in the papers of the Foreign Office General Correspondence Series (FO371) for Argentina, 
as well as in the files of the Treasury and the Board of Trade. ${ }^{26} \mathrm{He}$ was viewed by the Foreign Office as moderate and sensible and was prized because he had a good personal relationship with Yrigoyen. However, we do know how he viewed the 1929 trade mission. In January 1930, he was invited to give a lecture about its significance to Anglo-Argentine relations to the Institute of International Affairs in London. D'Abernon had addressed the same audience two months earlier, and it is interesting to compare their accounts. ${ }^{27}$ While D'Abernon viewed the success of the mission in terms of its ability to make its commercial case, Robertson was keen to emphasise the role played by Yrigoyen. ${ }^{28} \mathrm{He}$ saw many similarities between the foreign policies of Britain and Argentina. Both countries, he thought, had perfected the art of being 'genuinely neutral'. ${ }^{29}$ However, his definition of neutrality was not entirely how the term would be understood today; but was a policy of disengagement from the affairs of neighbouring states with the option of a more robust role should circumstances warrant it. Like the British, the Argentines were 'intensely pacific' and 'always ready to go to arbitration' with 'good grace'. Both countries shared an 'incredible tolerance' of foreign cultures that was 'hardly known outside these islands', stemming in part from the cosmopolitan nature of their respective trading communities. ${ }^{30}$ All of this was in marked contrast with the United States. While British policy towards South America was flexible, the Americans were constrained by the 'millstone' of the Monroe Doctrine. While Britain had historically been 
prepared to sign treaties that guaranteed, inter alia, territorial borders, the Americans had not. Consequently, 'the ugly word "Imperialism"' was frequently used to describe American commercial policy in Latin and South America. ${ }^{31}$ Robertson thought that Argentina might fall victim to American commercial 'imperialism' because international bodies such as the League of Nations would be powerless to prevent it because neither countries were members. ${ }^{32}$

Robertson played a central role in paving the way for the arrival of the trade mission. As early as December 1925, he had lobbied the British Chamber of Commerce in Buenos Aires on the need for a formalisation of relations between the two countries because the 'days of our absolute supremacy, indeed our virtual monopoly, have gone never to return. We have been ousted in many places, many lines. ${ }^{33}$ Robertson realised that this situation stemmed in part from a malaise within Britain's interwar economy that had seen exports stagnate at a time when there was growing international competition for a share of the market. ${ }^{34}$ As he later reflected 'we do not display the energy, imagination, enterprise and selling capacity of old. ${ }^{35} \mathrm{He}$ had good grounds for being concerned. As Robertson prepared for the arrival of the mission, the Argentine tabloid, La Action, claimed that the United States had designs on the Buenos Aires and Pacific Railway; a direct challenge to the British monopoly. ${ }^{36}$ Similar rumours began to circulate about American plans to buy up Standard Oil in Argentina. ${ }^{37}$ The British Chamber of Commerce concluded that the 
railways formed the 'backbone' of Anglo-Argentine relations; if that changed, 'we may as well pack up and get out. ${ }^{38}$

The D'Abernon mission arrived and was received by Yirigoyen on 21 August 1929. According to Robertson, D'Abernon's speech of welcome 'could hardly have been improved on'. ${ }^{39}$ In return, Yrigoyen promised that the mission would 'meet with every kind of facility and friendliness'. On 22 August, D'Abernon visited the Buenos Aires Stock Exchange, where he had received an 'ovation'. The Argentine newspaper, Nación, flamboyantly complemented the British government's decision to send a man of D'Abernon's status as head of the mission: 'Lord D'Abernon comes, converting into reality the hopes of our youth as a laborious people, and brings in the person of his collaborators a deep knowledge of the country.' Robertson assured the outgoing British Foreign Secretary, Arthur Henderson, that the work of the mission had started 'under the best possible auspices'. ${ }^{40}$ That said, D'Abernon's speech was quirky in that he talked more about how he had helped secure German economic recovery during his embassy in Berlin than about how the trade mission could optimise Anglo-Argentine commercial relations. Nevertheless, he used the occasion to make a number of sweeping rhetorical statements about how he viewed Britain's role in international diplomacy: 
The attitude of England throughout the whole of this period has been that of a world peace maker. We have endeavoured to compose differences between old antagonists and establish normal relations of friendship throughout Central Europe. What we desire is the reestablishment of favourable conditions for commercial interchange and commercial development. This is the intelligent interest of the whole world..$^{41}$

A speech made by D'Abernon on the same day to the British Chamber of Commerce in Buenos Aires adopted a similar tone. ${ }^{42}$ Robertson described it as being 'characterised by impressive optimism regarding British commerce and industry'. However, the most notable aspect of speech was the hint that there might have to be an increase in imperial preference in response to public opinion. D'Abernon also became something of a media celebrity during the mission's stay in the Argentine capital. All of his speeches were widely reported in the Argentine newspapers, although they received no verbatim coverage in the British press. The substance of his speech to the Chamber of Commerce was reported in La Prensa on 26 August; the article arguing that tariff protection was 'shortsighted'. Two days later, the British Financial Times published a letter from 'a constructive critic' that argued that 'there was always the possibility, should the industrial crisis in Great Britain become worse, of the adoption of imperial preference or free trade within the Empire. That D'Abernon had foreseen 'the storm cloud on the horizon' and had consequently been 
selected to head the mission. ${ }^{43}$ It was his role to 'persuade Argentine friends not to follow a policy that might conceivably send them well along the road to ruin'. The Diario Español took a different tack. It was keen to contrast the work of the British mission with that of its recently departed American counterpart: 'Contrary to what happened with the visit of Mr Hoover, which gave rise to justifiable resentment, that of Lord D'Abernon and his mission has caused general satisfaction in the whole republic, since Argentines are convinced that they have nothing to fear from the increase of economic and financial relations with the United Kingdom... ${ }^{44}$

So what then was the outcome of the 1929 British trade mission to Argentina? The negotiations concluded with an obligation on the part of the Argentine government to purchase nine million pounds worth of equipment for the railway system in return for British guarantees to buy a reciprocal amount of goods from the rural sector of the Argentine economy. Robertson believed that the British government had 'obtained something for nothing'. ${ }^{45}$ Furthermore, this had come about because Yrigoyen had wanted to make 'a great moral gesture' towards Great Britain. ${ }^{46}$ Not all Argentine politicians, however, appreciated Yrigoyen's magnanimity. When, in November 1929, the President announced a fifty percent tariff reduction on yarns and cloth containing artificial silk imported from Britain, Yrigoyen was criticised for being too accommodating. ${ }^{47}$ That said, the remainder of the terms of the agreement were approved by the Argentine Chamber with only little dissent, although it never came 
into law because the Yrigoyen government was ousted from office in a coup in September $1930 .{ }^{48}$ However, as early as December 1929 , there were already suggestions that the outcome of the trade mission had been too one-sided and that the domestic Argentine opposition was 'not exactly a good augury for the immediate progress of the treaty proposal. ${ }^{49}$ By June 1930 , public opposition to the agreement was vocal and direct. In the view of the newspaper, La Prensa, the Senate should reject a proposal that was 'ill-conceived and one-sided', although for complex constitutional reasons, that body was never formally asked to do so. ${ }^{50}$ The stalling led the British Chamber of Commerce in Buenos Aires to declare in November 1931 that the mission had been a failure. ${ }^{51}$ This conclusion was instrumental in the decision in the autumn of 1932 to revisit the outcomes of the D'Abernon mission, and the decision by the Argentines to despatch a delegation to London, headed by Vice-President Julio A. Boca. The resulting Boca-Runciman Treaty, concluded in 1933, had far-reaching effects on the structure of Britain's relations with Argentina.

It is clear that the main business of sorting out the fine technical details of the agreement was never D'Abernon's responsibility, but fell to Robertson. The main debate between the Foreign Office, the Treasury and the Board of Trade concerning how to bring the commercial agreement to fruition stemmed from a summary of three telegrams Robertson despatched to the Foreign Office on 2 September 1929. One possibility that the British government might like to consider, Robertson 
advised, was to make block purchases of Argentine goods. These would be cheaper overall and thus more beneficial to British industry. There was a useful precedent for this as it would mirror the agreement the Argentines had brokered with France two years earlier. Robertson was keen to emphasise, as he always had done, that it was vitally important for the British government to formalise commercial relations with Argentina because of the threat of competition from other European powers and from the United States. As he told Henderson: 'It would be tragic if we were to miss the present opportunity which is most favourable to us in every way and I earnestly beg that His Majesty's Government will give most sympathetic consideration to the principle of the proposals and send a reply at the earliest possible moment. ${ }^{, 52}$ In essence, this was to be the substance and tone of Robertson's message to the Foreign Office for the two months that followed, until his departure from Buenos Aires in November 1929.

However, Robertson's request for a clear steer on how to proceed and, later, for authorisation to sign the agreement on behalf of the British government, led to a period of hesitancy, procrastination and cumbersome bureaucratic wrangling in Whitehall. This undermined his position in Buenos Aires, and led to him being made a scapegoat for the slow progress in the negotiations by both the British and by the Argentine government. The principal protagonists in this debate were: Sir Edward Crowe, Comptroller General of the Department of Overseas Trade; Sir Thomas St 
Quintin Hill of the Board of Trade; and Sir Bernard Gilbert of the Treasury.

Robertson's despatches were also read and commented on by the head of the American Department at the Foreign Office, Thomas Maitland Snow. Created in 1865, the American department dealt single-handedly with all British foreign policy matter relating to North, Central and South America; a situation that did not change until the Eden Reforms of 1942-43 that saw the creation of three separate departments to deal respectively with these regions. ${ }^{53}$

It was Snow who brought to Crowe's attention Robertson's argument that 'Argentine produce must be given free entry into United Kingdom at any cost'. ${ }^{54}$ Snow asked the Department of Overseas Trade, the Board of Trade and the Treasury to collaborate to bring this to pass. Snow's contribution to the dialogue indicates that the Foreign Office wished to provide the main steer for the results of the negotiations while leaving the technical details to the Board of Trade and to the Treasury. ${ }^{55}$ This division of labour worked harmoniously for the most part, and provides an interesting contrast to the inter-departmental turf wars that occurred over, for example, the implementation and reform of the Reparation (Recovery) Act just a few years before. ${ }^{56}$ Likewise, there was also a clear hierarchy of departmental seniority during the discussions that required the Board of Trade to obtain the agreement of the Treasury for proceeding; a process that the Treasury was then required to adopt with the Foreign Office. The chain of command also worked in reverse, with 
material being passed from the Foreign Office to the Treasury and then on to the Board of Trade. Consequently, Crowe shared Robertson's despatch of 2 September with F. Phillips of the Treasury, who then passed it on to Sir Henry Payne at the Board of Trade. ${ }^{57}$

In Buenos Aires, Robertson was filled with a sense of urgency: 'I am more than ever convinced present opportunity of coming to terms with President should not be missed as immense immediate development of British trade is within reach. ${ }^{58} \mathrm{He}$ was also keen to ensure that the British government would expedite the implementation of the commercial agreement, ideally before the mission had left South America. ${ }^{59}$ The Board of Trade's response was more measured and reflective, but nevertheless agreed to approve the agreement subject to the resolution of technical details relating to methods of payments for goods. ${ }^{60}$ However, Robertson believed that even a minor delay would have negative repercussions for Britain's relations with the Yrigoyen government. Emphasising the closeness of his relationship with the President, Robertson argued that he was clamouring to 'give [a] striking example to the world of Argentine friendship for Britain' and that 'details are of little importance to him'. Yrigoyen was concerned that the mission should not leave 'without public evidence of definite achievement'. Robertson viewed 'with great alarm' any suggestion of a delay in signing the agreement. ${ }^{61}$ These despatches and some of those that followed also illustrate the negative side of his relationship 
with Yrigoyen; that the President expected Robertson to remove singlehandedly the obstacles that were to emerge to signature of the agreement. That he did not appreciate that Robertson had little influence over the methods of working of the departments of the British government that were dealing with the issues. D'Abernon was keen to offer his support for Robertson's sense of urgency. He informed the Board of Trade that Yrigoyen was prepared to add a clause to the agreement that would give preference to British contractors and that the Argentine president 'regarded [the] economic mission as a most important event within the history of the country., ${ }^{, 62}$

Robertson worked closely with D'Abernon, the former often reining in the latter's natural tendency towards gushing over-optimism. After a three hour meeting with Yrigoyen on 7 September, the two men had managed to persuade the Argentine President to agree to all aspects of the commercial agreement. The only sticking point was the question of publication of the terms. D'Abernon reported that Yrigoyen insisted that full disclosure was 'indispensable before the departure of the Mission. ${ }^{93}$ However, both realised that such an eventuality was unlikely because the British government would not permit full publication until it had been ratified by Parliament. This point seems to have been lost on Yrigoyen, although there is little evidence that Robertson tried to explain this aspect of British constitutional law to the Argentine. That said, Robertson's telegrams to the Foreign Office suggest that he 
and D'Abernon were under pressure to agree to the publication of the agreement irrespective of the position of the British government. He told Henderson that 'we did all we could to delay it.' But that Yrigoyen had made it clear to them that any postponement would have led to 'serious danger of this very important convention being lost'.64

Robertson's solution was to ask Yrigoyen whether he would be satisfied if the British government agreed to publish a summary of the agreement, rather than the complete text. He sought permission to this effect from the Foreign Office. Robertson argued that such a move could be couched as a gesture of good faith between the two governments. ${ }^{65}$ But Robertson was stymied by an eight day hiatus during which the Foreign Office, the Treasury and the Board of Trade mulled over their response. There are other examples of an ambassador being left without instructions for a similar period in such circumstances within the annals of British commercial diplomacy during the 1920 s, and the impression that such a bureaucratic approach to diplomatic decision making conveyed abroad seems to have been of little consequence to the British government. ${ }^{66}$

On 17 September, Henderson drafted a telegram that appeared initially to hold out hope of a positive response to Robertson's suggestion. The Foreign Secretary 'fully appreciated' the necessity of the negotiations being brought to a denouement 'as 
rapidly as possible. ${ }^{67}$ However, he gave no indication that he intended to acquiesce in Robertson's request but announced instead that he wished to confer further with the Board of Trade and with the Treasury. This process took a further eight days, the result of which was a letter from Hill to Phillips stating that the Board of Trade were content to approve a summary of the agreement for publication. ${ }^{68}$ The Treasury remained silent. By this time, Robertson's position had become more exposed because he had lost D'Abernon as an ally in negotiating with Yrigoyen, as the mission had left Buenos Aires on 8 September for Montevideo.

Its departure also brought about a change in the attitude of the Argentine President in his dealings with the British government. The polite platitudes about concluding a mutually beneficial trade agreement and the importance of having Britain as a trading partner were replaced by increasingly hardnosed requests for amendments and adjustments to the text. Many of these were complex and technical and of the kind that Robertson felt compelled to seek expert advice from London. By 25 September, Robertson had grown tired of waiting for instructions and expressed his frustration in a plainly worded telegram to Henderson. Yrigoyen, Robertson argued, was 'feeling injured and anxious' by the attitude of the British government to signing the agreement and requested that 'you will find it possible to send me full powers very soon. ${ }^{69}$ 
The following day, Robertson finally received his instructions, but they were not what he was hoping for. ${ }^{70}$ The Foreign Office, the Treasury and the Board of Trade remained embroiled in the legal question about publication of the text of the agreement and whether there was any way of expediting the process of ratification. Furthermore, closer inspection of the agreement by the Treasury and Board of Trade had revealed a number of queries that would have to be resolved before the agreement could be ratified. Robertson therefore received the powers to sign the commercial agreement on behalf of the British government but only after all of these matters had been resolved. ${ }^{71}$ Again he chose to wait before expressing his frustration. By mid October, he had come up with his own solution to the delay. He asked Henderson permission to sign the agreement but to 'leave details of operation to be worked out subsequently by financial experts' in order to avoid 'endless delays' ${ }^{72}$ However, the Treasury and Board of Overseas Trade rejected this idea, anticipating that 'while desiring to be helpful' it would 'only put us all into a fresh difficulty. ${ }^{73}$ The problem being that both departments continued to anticipate that the plan would require an Act of Parliament; an opinion Robertson did not share. ${ }^{74}$ He saw little reason why the British government could not sign at least part of the agreement, an opinion shared by Yrigoyen. The President interpreted the delay as a lack of British faith in Argentine sincerity and was at pains to impress on Robertson 
that he held the 'most affectionate regards' for trading with Britain and that his 'sympathy and good feelings' increased 'every day. ${ }^{, 75}$

By 17 October, Hill was starting to become receptive to Robertson's suggestion. Not least because of concerns that delay might impede the flow of Anglo-Argentine trade. At the same time, Hill harboured concerns that the appointment of a panel of experts to resolve the fine details of the agreement might hamper any further commercial initiatives between the two countries. Furthermore, the deliberations of the experts might add rather than remove levels of technical complexity. It was important that any 'possibility of signature under misunderstanding should be avoided at all costs. ${ }^{76}$ Before authorising instructions to Robertson, Hill requested more time to consider the matter and suggested enlisting the advice of the Lord Privy Seal, James Thomas. ${ }^{77}$

In Buenos Aires, Robertson's anxieties about the agreement escalated when the Argentine Congress failed to form a quorum to ratify it. In a telegram that was to have long lasting repercussion, Robertson vented his spleen to Henderson on 28 October. ${ }^{78}$ Robertson believed that an insufficient number of deputies had attended the debate on the commercial treaty because they thought that the British government had lost interest in it. He felt 'considerable uneasiness' about the future of the agreement and chastised the Foreign Office for not authorising him to sign it at an 
earlier point in the negotiations. As he put it: 'The iron is growing very cold and I cannot now guarantee that President would agree to signature even if I received necessary authorisation.' A further reason why the agreement was viewed negatively was because it 'gives us every advantage and Argentine none.' Furthermore, other countries that wished to trade with Argentina had used the hiatus in the negotiations 'to prosper'. ${ }^{79}$ Robertson was also unhappy with the continuing long silence from the Foreign Office, Board of Trade and the Treasury: 'Neither my financial adviser here nor I can understand what risks are being incurred by HMG compared with importance of securing unexpected orders for British industry.' His sense of helplessness and frustration were compounded by the fact that he had received no concrete instructions for more than a fortnight. ${ }^{80}$

Robertson's telegram compelled Snow to call a conference with representatives of the three government departments involved in the commercial negotiations the following day. The only record of what was said is a long memorandum from Gilbert to his Treasury colleague, Phillips. ${ }^{81}$ This makes it clear that Gilbert saw Robertson as being partly responsible for the hiatus. 'The ambassador appears to have done nothing...and it is not clear that either the agreement or the supplementary note [concerning suggestions for amendments] has ever been put to the President. ${ }^{82}$ Robertson had been too willing to accommodate Yrigoyen and there was no 'reason for not being able to get him to look at the details.' Gilbert's account makes it clear 
that the Foreign Office and the Board of Trade were more sympathetic to Robertson's plight and had 'taken seriously' his arguments about the effect of prolonged delay on Anglo-Argentine commercial relations. What follows in this important insight into how British commercial diplomacy worked at this time is also very revealing for another reason. It demonstrates that in negotiating the commercial agreement with the Argentine government, the British government had always been aware that the terms were far more beneficial to Britain. That in Argentina there was a 'growing realisation that all the benefit is on our side.' ${ }^{83}$ Consequently, the time had now passed for a successful conclusion of the agreement.

Gilbert's analysis elicited strong objections from Crowe and from Sir Horace Hamilton, the Permanent Secretary to the Board of Trade. Both felt that to withdraw from the agreement would 'be a serious blow for our trade, not merely in the Argentine but in S[outh] America generally. ${ }^{84}$ The President of the Board of Trade, William Graham, 'felt strongly that the agreement ought not to fall through any fault on our side.' That he would be willing to support any legislation that was necessary to enable the British government to uphold its half of the agreement. But in order to guarantee the value of the goods coming from Argentina, Robertson should be authorised to sign the agreement on condition that items were quoted in gold pesos and that it would only come into operation on ratification rather than on signature. ${ }^{85}$ Concerns were expressed by Snow, Crowe and others about linking Argentine 
exports to the value of the peso; in which case, should a financial margin be built into the value of the exports should the currency depreciate in value? ${ }^{86}$ A minute by the Treasury confirmed its unwillingness to 'agree to the signing of the main agreement in its present form.' But the plan to link the value of exports to the peso was 'likely to hold thing up'; concerns that formed the basis of a memorandum to the Board of Trade. $^{87}$

Gilbert appreciated that if the commercial agreement with Argentina was not signed, it would make the Board of Trade 'very sad', but the 'real trouble' was that 'the Argentine government have realised that it gives much to us and nothing to them.' The desire of the Board of Trade to push forward for signature was likely to make it 'extremely difficult to get from them afterwards a working understanding.' Consequently, there were 'thus very strong arguments for refusing to commit ourselves'. The Argentines were free to trade with Britain irrespective of whether there was a trade agreement in place or not. Gilbert then went on to criticise D'Abernon's role in the negotiations. In all probability 'the agreement by itself means very little' to the Argentines and that, in reality, it amounted to little more that 'a stubborn financial facade built by Lord D'Abernon round whatever argument he used to persuade the Argentines [to sign the agreement]'. It was now clear that the Argentines were now 'apparently anxious to get away from the bargain' ${ }^{88}$ That said, 
Gilbert was willing to support the Board of Trade's view that Robertson should be allowed to sign the agreement, even though 'I do not at all like the position. ${ }^{\text {, } 9}$

However, Robertson now faced fresh difficulties. His analysis of Yrigoyen had proved to be accurate, and by late October 1929, it was clear that the Argentine President intended to use the delay in signing the commercial agreement to drive a harder bargain with the British government. Robertson was unaware of the substance of the inter-departmental debate that was taking place in London. But as if to underline the misgivings expressed by Gilbert, Yrigoyen coincidentally chose that point by stating that the Argentine government would not sign the agreement if its terms continued to be applied to meat products as well as to cereals. This represented a major new development in the negotiations because Robertson was fully aware that an agreement concerning meat products, railway rolling stock and tariffs on artificial fabrics formed the core of the agreement. Robertson tried to persuade Yrigoyen to abandon the idea: 'I used what arguments I could but failed to move him. ${ }^{90}$

In London, the response to Robertson's latest missive about Yrigoyen's change of tack was twofold. It galvanised Hill into drafting a set of draft instructions, which he also circulated to the Treasury and the Foreign Office, authorising Robertson to sign the commercial agreement with immediate effect. ${ }^{91}$ The debate about Hill's text then 
resulted in a letter from the Foreign Office to the Treasury that made it clear that senior members of that department did not share the latter department's doubts about Robertson's competence. In a neat political pirouette, the Foreign Office placed the responsibility of educating Robertson about 'the risks and difficulties to which it is anticipated that the trade agreement with Argentine might give rise' firmly at the door of the Treasury. ${ }^{92}$ In the meantime, the Foreign Office was keen to demonstrate continued faith in Robertson by advising how he could persuade Yrigoyen to have a change of heart over the beef issue. On 6 November, Robertson proved worthy of the confidence of his masters and reported that he had managed to persuade Yrigoyen to drop his objection. ${ }^{93}$ Two days later, he received the authority to sign the commercial agreement between the British and Argentine government, some two months after the departure of the D'Abernon mission from Buenos Aires. On 9 November, Robertson received a lengthy telegram summarising what had been the Treasury objections but in a format that made it clear that the Foreign Office believed that the cause of the delay in signing the commercial agreement lay not with Robertson, but with the Argentine government: 'All of these risks would be obviated if you are able to obtain consent of President to working arrangements set out in telegram that had been in the hands of the Argentine minister for foreign affairs for five weeks. ${ }^{94}$ A week later, Robertson returned to London, to be replaced as ambassador in Buenos Aires by Eugen Millington-Drake. In a letter that was clearly 
intended to convey Foreign Office faith in Robertson, Snow recommended to Gilbert that 'we should be fortified' by his 'authoritative opinion'. 95 But for Robertson this demonstration of confidence came too late; he immediately retired from the British Diplomatic Service, surrendering his pension.

Commercial relations between states are a relatively understudied aspect of international history. They are frequently viewed as either secondary to the politics of diplomatic interaction or as a dry, inaccessible area of investigation, the province only of those with a technical knowledge of economic history and theory. However, historians of the modern industrial world overlook them at their peril. During the nineteenth and twentieth century, international trade formed the basis of the imperial power and reach of the majority of the larger states in Europe and established for the first time the notion of a global economy. Thus commercial diplomacy should be at the heart rather than at the periphery of how we view all aspects of British and French imperial history, for example. Historians are not as good at this as they should be. Still less are they willing to venture into the world of what could be termed the statecraft of commercial diplomacy, that is, the establishment and operation of the various government infrastructures that existed to facilitate and lead this aspect of national foreign policy. The purpose of this article has been, in part, to provide a reminder of the existence of these factors and how they operated in one case study. That said, it is far from remarkable to conclude that, in the great scheme 
of British commercial imperial and foreign policy in the twentieth, relations with the countries of South America was not a major priority. That was the case throughout the first half of the twentieth century and beyond; the 1929 trade mission therefore changed little in the long as well as in the short term. Yet studying this small snapshot of Anglo-Argentine relations does offer some important insights into the British diplomatic mindset abroad. First, there is the figure of D'Abernon himself. Although very much a man of the moment in 1929 , this septuagenarian hardly epitomised the image of the post-First World War modern model of British diplomat. While he was undoubtedly a financial expert, his intellectual and linguistic reference points were very much that of a late nineteenth century imperialist. It was never his intention to bring an element of equilibrium to Anglo-Argentine relations but simply to ensure that the imbalance that had existed since the 1880 s continued to operate in Britain's favour. It is, of course, the purpose of any financial negotiation to achieve the optimum deal with the minimum of concessions to the partner, but the trade mission of 1929 did this through the use of openly imperialist language. Indeed, both D'Abernon and Robertson clearly wrote about Argentina as a kind of informal member of the British Empire in a way that would have been unthinkable in a discussion of Britain's relations with the equally modern European economies of, for example, Germany and France. Second, there is the notion of distance. Robertson's experience does convey a strong sense that a posting to South America marked the 
graveyard of ambition for a British diplomat. But, it is interesting to consider whether one reason why South America was viewed in this semi-imperialist manner was because, quite literally, it took as long to reach as parts as Britain's principal imperial territories. The practicalities of diplomatic contact especially would also have been the same. Third, there is the question of the strategic aspirations of the United States and how they influenced British diplomacy in South America. The context to the mission, its work and the aftermath of the commercial agreement that stemmed from it suggests that the notion of a British-American rivalry for influence in the region can be overstated. ${ }^{96}$ The evidence from Robertson's despatches and D'Abernon's comments suggest that if there was a turf war at all, it was largely rhetorical. The possibility that the American government could steal Britain's thunder in commercial relations with Argentina was a useful ploy to chivvy along the negotiations but never amounted to a legitimate, sustained threat. That is not to suggest that the United States had little interest in trading with the most modern economy in South America or that we should downplay the importance of the Monroe Doctrine to American foreign policy. Both were significant, but not of as great a magnitude to the United States during the massive boom period of economic and commercial expansion in the 1920s as capitalising on the post-First World War recovery in Europe. The diplomatic climate of the post-Second World War period, however, did change that dynamic, as the United States' government fear about the 
spread of communism in Latin and South America grew. Finally, this article provides an insight into the statecraft of British commercial diplomacy and how the bureaucracy of inter-departmental co-operation tended to hamper rather than expedite the formation of policy and the despatch of diplomatic instructions. In the decade since the end of the First World War, the organisation of the Foreign Office in particular had undergone radical change, through the expansion in the number of geographical departments and through the greater democratisation of recruitment to the British Diplomatic Service. ${ }^{97}$ This took place against the backdrop of the unprecedented complexity of post-war diplomacy, combined with the growing ambition of other government departments to play a role in the foreign policy formulation process. As Robertson's experience demonstrated, the results of these changes had yet to produce an efficient framework within which to consider aspects of commercial diplomacy. This was a situation that remained unchanged as the 1920s gave way to the third decade of the twentieth century that offered very different challenges to the international community. 
Notes

1 R. Gravil, 'Anglo-American rivalry in Argentina and the D'Abernon Mission of 1929', in D. Rock (ed.), Argentina in the twentieth century (Pittsburgh: University of Pittsburgh Press, 1975), 41-65.

2 D. Rock, (ed.), Argentina in the Twentieth Century (Pittsburgh: University of Pittsburgh Press, 1975).

3 Viscount D’Abernon, 'The Economic Mission to South America', Journal of the Royal Institute of International Affairs (Nov. 1929), 568-582; Sir M.

Robertson, 'The economic relations between Great Britain and the Argentine Republic', Journal of the Royal Institute of International Affairs (March 1930), 222-230.

$4 \quad$ Gravil, op.cit.

$5 \quad$ Ibid.

$6 \quad$ P.B. Goodwin, 'Anglo-Argentine Commercial Relations: A Private Sector View, 1922-43’ Hispanic American Historical Review, (61), 1981, 29-51; C. Solberg, 'The tariff and politics in Argentina, 1916-1930' Hispanic American Historical Review (53), 1973, 260-204; J.S. Tulchin, 'Decolonizing an 
informal empire: Argentina, Great Britain and the United States, 1930-1943' International Interactions (1), 1974, 123-140.

T. dos Santos, La crisis de la teoría del desarrollo y las relaciones de dependencia en America Latina (Santiago, 1968), 26-27.

In British government documents and correspondence, his surname was often anglicised as Irigoyen. President of Argentina: 1916-1922 and 1928-1930. F. Luna, Yrigoyen (Buenos Aires, 1964); E.F. Guiffra, Hipólito Yrigoyen en la historic de las instituciones argentinas (Buenos Aires, 1969). View, 1922-43’ Hispanic American Historical Review, (61), 1981, 30. There is an extensive literature on the Falklands War, but see especially A. Donaghy, The British Government and the Falkland Islands, 1974-1979 (Basingstoke: Palgrave Macmillan, 2014); M.A. Gonzalez, The Genesis of the Falkland (Malvinas) Conflict: Argentina, Britain and the Failed Negotiations of the 1960s (Basingstoke Palgrave Macmillan, 2014). On Peronism, see M.B. Karush and O. Chamosa (eds), The New Cultural History of Peronism: 
Power and Identity in Mid Twentieth Century Argentina (Durham, North Carolina, Duke University Press, 2010).

11 C. Solberg, 'The tariff and politics in Argentina, 1916-1930' Hispanic American Historical Review (53), 1973, 260-204.

12 C. F. Jones, "Argentine Trade Developments," Economic Geography, 2 (1926), 358.

13 Solberg, 262-3.

14 J.E. Richelet, La ganaderia argentine y su comercio de carries (Buenos Aires, 1928), 141-146.

16 Gravil, 47.

17 G. Connell-Smith, The Inter-American System (London, 1966), 78.

18 Foreign Office Memorandum, 25 October 1929, cited in Gravil, p. 50. 
Ibid.

Ibid.

Foreign Office Memorandum, 15 October 1929, cited in Gravil, 52.

22 Follett Holt commenting on D'Abernon, 'The Economic Mission to South America', 572-3.

$24 \quad$ Ibid.

25 Ibid.

26 There is a small collection of Robertson private papers in Churchill College Archive Centre, University of Cambridge, UK, class mark RBTN. These include an unpublished memoir written during the Second World War. However, the papers do not add substantially to the public record on his embassy in Argentina. 
${ }_{27}$ Viscount D'Abernon, 'The Economic Mission to South America', Journal of the Royal Institute of International Affairs (Nov. 1929), 568-582; Sir M.

Robertson, 'The economic relations between Great Britain and the Argentine Republic', Journal of the Royal Institute of International Affairs (March 1930), 221-6.

28 Robertson, 'The economic relations between Great Britain and the Argentine Republic', 223.

Ibid.

Ibid. Ibid.

Ibid., 224. Argentina had failed to join the League at its inception in 1919 because the Covenant, outlining the rules of membership, appeared to allow the United States to preserve the Monroe Doctrine. See M.T. Gilderhus, 'The Monroe Doctrine: Meaning and Implications' Presidential Studies Quarterly (36) $12006,5-16$. 
$33 \quad$ Speech of 17 December 17 1925, cited in Robertson, op.cit.

34 D.H. Aldcroft, The Inter-War Economy Britain, 1919-1939 (New York: Penguin, 1970), 253.

35 Robertson, 'The economic relations between Great Britain and the Argentine Republic', 224.

$36 \quad$ La Action (Buenos Aires), 13 May 1929, 1.

37 C. E. Solberg, Oil and Nationalism in Argentina: a history (Stanford: Stanford University Press, 1979), 140-141.

$38 \quad$ Ibid., 19-20.

$40 \quad$ Ibid.

$41 \quad$ Ibid.

42 Robertson to Henderson, 31 August 1929, A6604/52/2, British Documents on Foreign Affairs (hitherto BDFA), Series D, Part II, Vol. 6, Latin America, 1929-1930, 130. 

boom in the late 1920 s, the international community was on the verge of a major recession and crisis of financial confidence. This he explored in The Economic crisis: its causes and the cure (London: Hodder and Stoughton, 1931). A8336/52/2.

45 Robertson, 'Economic Relations', 228.

46 G. del Mazo, El Radicalismo 3 vols., (Buenos Aires, 1957), II, 122-125. See also British Chamber of Commerce in the Argentine Republic Monthly Journal, vol. 10, November 1929, 22-3. Robertson to the Foreign Office, 10 September 1929, BDFA, Series D, Part II, Vol. 6, Latin America, 1929-1930, 98. Memorandum on the Subject of the duty on goods containing artificial silk, 3 September 1929, Ibid., 180. Kennedy (London, 1966), 19-20. 
Ibid.

49 Review of the River Plate, 20 December 1929, 5.

50 La Prensa, June 24, 1930, 12. See also Review of the River Plate. 24 January 1930, 17.

51 BCC, 'Council Minutes,' 10 November 1931, cited in Solberg, Oil and Nationalism, 56.

Robertson to Henderson, 2 September 1929, A5855/52/2, TNA/T160/276.

It is worth noting that D'Abernon and Robertson lobbied the British government for a separate South American department at the Foreign Office in 1929-1930 in recognition of the region's 'special status', but to no avail. Report of the British Economic Mission to South America August-September 1929, on commercial diplomatic representation in Argentina, 12 December 1929, TNA/BT61/38/3. The first head of the South American department was Sir David John Montagu Douglas Scott.

54 Robertson to Henderson, 2 September 1929, A5634/52/2, TNA/T160/276. 
55 Snow to Edward Crowe, 3 September 1929, TNA/T160/276.

56 Cf. G. Johnson, 'Sir Ronald Lindsay, the British Government and the Reparation (Recovery) Act, 1927-1928' in R. Smith, E. Pedaliu and J. Fisher (eds), British Commercial Diplomacy in the Twentieth Century (London: Ashgate), forthcoming.

57 Crowe to Phillips, 4 September 1929, TNA/T160/276; Phillips to Payne, 6 September 1929, TNA/T160/276.

58 Robertson to Henderson, 4 September 1929, TNA/T160/276.

$59 \quad$ Ibid

60 Board of Trade to D'Abernon, 6 September 1929, TNA/T160/276.

61 Robertson to Henderson, 7 September 1929, TNA/T160/276.

62 D'Abernon to Board of Trade, 7 September 1929, TNA/T160/276.

63 Ibid.

${ }_{64}$ Robertson to Henderson, 8 September 1929, TNA/T160/276.

65 Robertson to Henderson, 9 September 1929, TNA/T160/276.

66 The substance of Johnson, 'Sir Ronald Lindsay'. 
67 Henderson to Robertson, 17 September 1929, TNA/T160/276.

68 Hill to Phillips, 25 September 1929, TNA/T160/276.

69 Robertson to Henderson, 25 September 1929, TNA/T160/276.

70 Henderson to Robertson, 26 September 1929, TNA/T160/276.

$71 \quad$ Ibid.

72 Robertson to Henderson, 15 October 1929, TNA/T160/276.

73 Hill to Crowe, 24 October 1929, TNA/T160/276.

74 Robertson to Henderson, 15 October 1929, TNA/T160/276.

75 Robertson to Henderson, 21 October 1929, TNA/T160/276.

$76 \quad$ Hill to Phillips, 17 October 1929, TNA/T160/276.

77 Argentine Agreement, Notes for the Lord Privy Seal, 17 October 1929, TNA/T160/276.

78 Robertson to Henderson, 28 October 1929, TNA/T160/276.

$79 \quad$ Ibid.

$80 \quad$ Ibid. 
81 Minute by Gilbert to Phillips, 29 October 1929, TNA/T160/276.

82 This argument is even more apparent in a memorandum from Gilbert to William Graham at the Board of Trade. 'It is quite clear where the responsibility for this difficult situation lies...Nothing at all appears to have been done by the Ambassador to carry out his instructions and the delay has apparently allowed time for second thoughts in the Argentine to arise.' Gilbert to Graham, 31 October 1929, TNA/T160/276. Minute by Gilbert to Phillips, 29 October 1929, TNA/T160/276. Ibid. Ibid. Minute by Crowe, 31 October 1929, TNA/T160/276.

87 Treasury minute, 30 October 1929, TNA/T160/276. Minute by Gilbert, 31 October 1929, TNA/T160/276. 
89 Gilbert to Graham, 31 October 1929, TNA/T160/276.

Robertson to Henderson, 31 October 1929, TNA/T160/276.

Hill to Phillips, 31 October 1929, TNA/T160/276.

Foreign Office to Hopkins, 2 November 1929, TNA/T160/276.

Robertson to Henderson, 6 November 1929, TNA/T160/276.

94

Foreign Office to Robertson, 9 November 1929, TNA/T160/276.

95 Snow to Gilbert, 9 November 1929, TNA/T160/276.

96

It should be noted that this was not the view taken by the Foreign Office in 1930 in explaining the fall of the Yrigoyen government. See, for example, 'Memorandum on desire of the Diadema Company to construct a refinery in Argentina, 24 February 1930', BDFA, Series D, Part II, Vol. 6, Latin America, 1929-1930, 176.

97 See, for example, inter alia, Z. Steiner, The Lights that Failed: European International History, 1919-1933 (Oxford: Oxford University Press, 2005) and also her article with M.L. Dockrill, 'The Foreign Office Reforms, 19191921’ Historical Journal (17), 1, 1974, 131-156. 